\title{
Correction to: Cochran's Q Test of Stimulus Overselectivity within the Verbal Repertoire of Children with Autism
}

\author{
Lee Mason ${ }^{1,2} \cdot$ Maria Otero $^{1,3} \cdot$ Alonzo Andrews $^{4,5}$ \\ Published online: 18 October 2021 \\ ๑) Association for Behavior Analysis International 2021
}

\section{Correction to: Perspectives on Behavior Science https://doi.org/10.1007/s40614-021-00315-w}

This article was update to correct an error introduced in Eq. 5 during the production process after authors had reviewed the proofs.

Publisher's Note Springer Nature remains neutral with regard to jurisdictional claims in published maps and institutional affiliations.

The original article can be found online at https://doi.org/10.1007/s40614-021-00315-w.

Lee Mason

lee.mason@cookchildrens.org

1 Child Study Center, Cook Children's Health Care System, 1300 West Lancaster Avenue, Fort Worth, TX 76102, USA

2 Texas Christian University, Fort Worth, TX, USA

3 University of North Texas, Denton, TX, USA

4 University of Texas at San Antonio, San Antonio, TX, USA

5 San Antonio Independent School District, San Antonio, TX, USA 